\title{
PRELIMINARY IDENTIFICATION OF THE AGENT CAUSING THE FUNGAL DISEASE OF ALDROVANDA VESICULOSA
}

Iveta Svobodová • Central Institute for Supervising and Testing in Agriculture • Šlechtitelů 23

-CZ-77900 Olomouc•Czech Republic・iveta.svobodova@ukzuz.cz

LuBomír AdAMEC • Institute of Botany of the Czech Academy of Sciences • Dukelská $135 \bullet$ CZ-379

01 Třeboň $•$ Czech Republic・lubomir.adamec@ibot.cas.cz

Keywords: Aquatic carnivorous plant, shoot apex damage, disease symptoms, fungal agent, Pythium, Phytopythium, Oomycetes, curing.

Abstract: Aldrovanda vesiculosa L. (Droseraceae) is a critically endangered and rare aquatic carnivorous plant. Growers of Aldrovanda have observed a disorder of shoot apices called "Aldrovanda disease". The fungal pathogen of the genera Phytopythium and Pythium of the class Oomycetes was repeatedly found to probably cause the disease. The pathogen occurs permanently in the sedge litter in aquaria or containers, but the factors responsible for its pathogenicity remain unknown.

\section{Introduction}

Aldrovanda vesiculosa L. (Droseraceae) is a critically endangered and rare aquatic carnivorous plant of the Old World. It is $8-15 \mathrm{~cm}$ long, rootless, free-floating, and grows just below the surface in shallow standing dystrophic waters (Breckpot 1997; Cross 2012; Adamec 2018a). In the last 20 years, it has been the subject of extensive ecophysiological research on photosynthesis, mineral nutrition, physiological polarity, growth traits, importance of carnivory, winter bud (turion) overwintering (for the review, see Adamec 2018a,b) as well as on molecular genetic study (Elansary et al. 2010). To support its very rapid apical shoot growth ( $>1$ new leaf whorl a day), it has to take up all necessary mineral nutrients including microelements only from nutrient-poor water or animal prey, besides having very effective re-utilization of $\mathrm{N}$ and $\mathrm{P}$ from senescent shoot segments (Adamec 2018b).

Probably, the majority of world growers of Aldrovanda have observed a disorder of shoot apices called "Aldrovanda disease" (Adamec 1997, 2003, 2007). In the world's largest collection of Aldrovanda populations in the Institute of Botany at Třeboň, Czech Republic, the disease has been observed every year since 1994. The disorder is manifested mainly as a damage (malformation), yellowing and, finally, blackening and dying of shoot apices (Fig. 1 left). Due to this disease, the apical shoot growth is slowed down and later is ceased. Unlike a healthy shoot apex of Aldrovanda, which is large, onion-shaped and "hairy" due to long spreading bristles (Fig. 1-Inset), the ill one is small and flat, yellowish, and with less conspicuous, shorter bristles (Fig. 1 right). Earliest, ill shoot apices form reduced bristles in developing leaves and this is, together with yellowing of the apices, the first observable symptom of the disease. Later, the apices cease forming new leaf whorls, are small and narrow and contain yellowish dwarfish leaflets. The internodes within the apex are also shortened. After several weeks, ill apices become brown-black as a tissue necrosis occurs. At this state, ill plants usually start forming new branches from leaf axils in older shoot segments. However, these new branches usually become infected sooner or later. The disease can rarely disappear and the regenerating axillary branches can be healthy. The disease usually infects gradually all individu- 

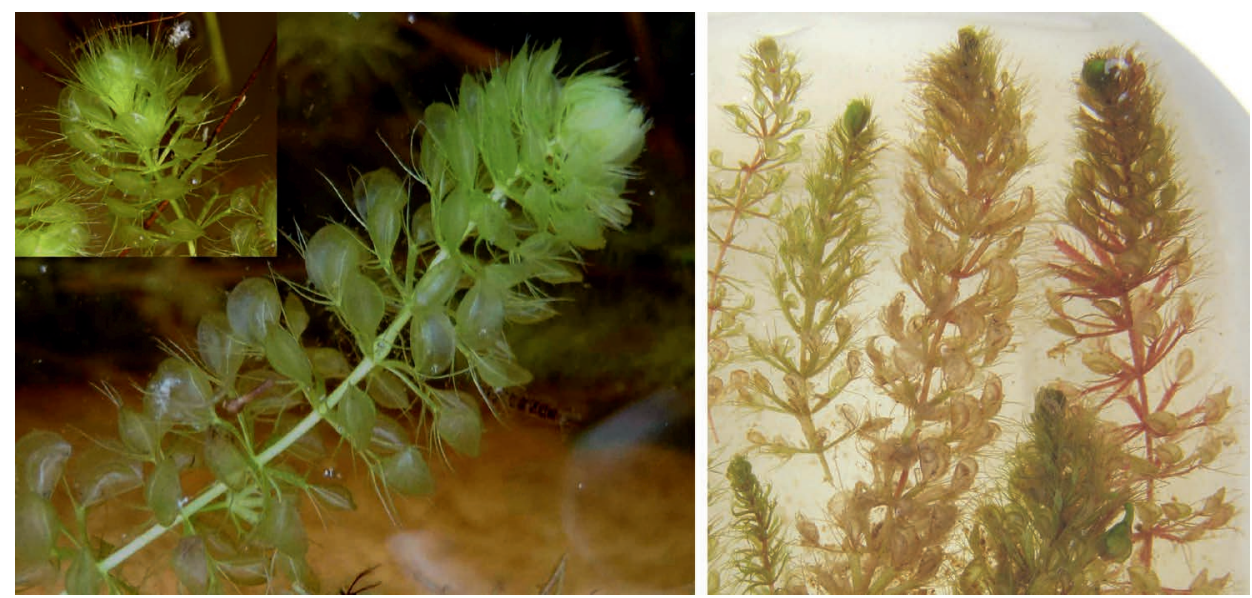

Figure 1: (Left) III E. Polish Aldrovanda plant with the typical beginning apical symptom of the disease. The inset (upper left corner) shows a healthy shoot apex for comparison. (Right) III reddish Hungarian Aldrovanda plants collected from sand-pit at Suchdol nad Lužnicí, South Bohemia, Czech Republic, in August 2012. All shoot apices shown are malformed with short bristles. III individuals possessing various type of disorder represented only $<2 \%$ of all plants. Photos by Lubomír Adamec.

als within an aquarium or even large container and can kill all plants in the culture if not cured. Moderately ill plants can form ill turions, which either rot over winter or cannot sprout in the next spring.

The described "apical symptoms" of the Aldrovanda disease are the most common but not the only ones: we have also found damage (rotting) of stems, in some cases $12 \mathrm{~mm}$ below the shoot apex (Fig. 2). Infected stems are orange-brown but the apices of such ill plants are smaller and yellowish though without apparent symptoms of malformation. This "stem symptom" is much rarer than the "apical" one and mainly occurs in small young plants sprouting from turions overwintered in the refrigerator in the spring. Surprisingly, a similar disease infects also some aquatic Utricularia species. In the Třeboň collection, it strongly infected and killed Asian U. aurea (Fig. 3) or African $U$. inflexa, while turion-forming temperate species U. vulgaris, U. macrorhiza, U. australis, and $U$. tenuicaulis can be infected much weaker and mainly in association with sprouting of their turions.

Since 1994, when the "Aldrovanda disease" was first observed, valuable pieces of knowledge on ecological and physiological traits of the disease have been obtained. Firstly, the disease has been manifested mainly in Aldrovanda cultures, while its field occurrence at nearly-natural artificial sites (introductions) in South Bohemia, Czech Republic, has been much weaker (Fig. 1). In line, it has never been observed at natural sites in Poland, Hungary, or Northern Macedonia. Moreover, in the cultures, it has been much more often observed in large opened cultivation containers (0.8-2 $\mathrm{m}^{2}$ ) than in small 3-1 aquaria permanently covered by Petri dishes. This suggests that the etiological agent enters the media with Aldrovanda regularly from the air. The denser the cultures are, the more often they can be infected. Interestingly, the more cultivated plants are fed on zooplankton and, thus, the more rapidly they grow, the faster and easier they can be infected. Poorly growing plants (e.g. shortage of $\mathrm{CO}_{2}$, filamentous algae) are much less infected. In contrast, flowering specimens are rather sensitive to the disease. Ill plants transferred to an aquarium with healthy plants may not infect the healthy individuals, but healthy plants transferred to an aquarium with ill plants usu- 


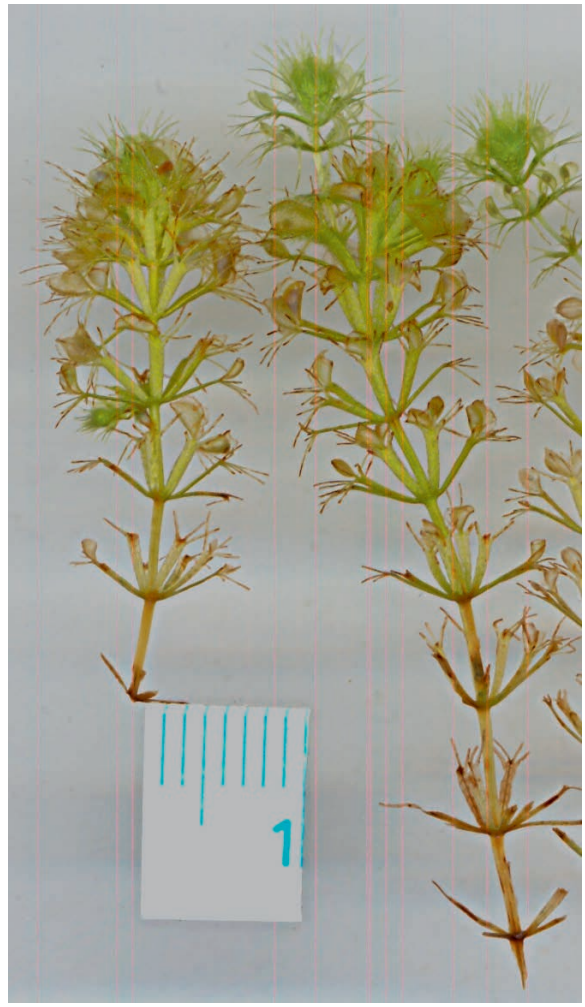

Figure 2: III Swiss/German Aldrovanda plants with typical stem symptoms of the disease. Ticks represent $1 \mathrm{~mm}$. Photo by Lubomír Adamec.

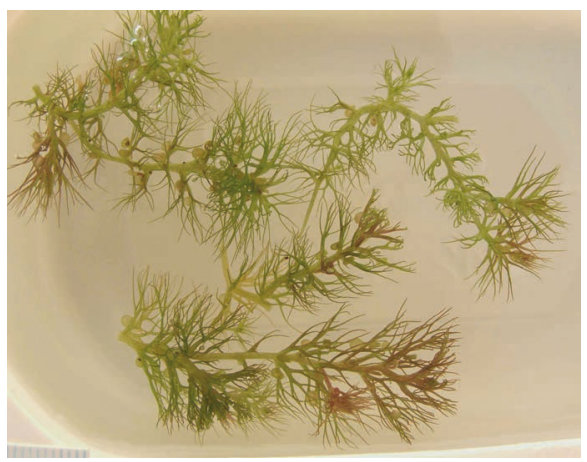

Figure 3: Utricularia aurea exhibiting symptoms of the disease. Photo by Lubomír Adamec. ally become ill. When ill plants (e.g. Polish) were transferred to a field site they completely became healthy in 2-3 weeks. Thus, the infectious character of the disease is not too strong.

By 2014, the disease has never been observed in the field in the Czech Republic, though the negligible minority of field-grown plants (ca. $<1-2 \%$ ) sometimes exhibited a damage of shoot apices similar to the disease in cultures. In 2015 and later on, this disease nearly killed two very abundant, prolifically flowering micropopulations (4000-6000 plants) of introduced Hungarian Aldrovanda in two small pools in a sand-pit complex near Suchdol nad Lužnicí, South Bohemia, Czech Republic (for the site, see Cross 2012; Cross et al. 2016; Fig. 1 in Adamec 2018c). Here, clearly ill plants represented ca. $10-20 \%$ of all individuals (Fig. 1). In these sand-pit pools, the boom of the disease was evidently associated with hot and dry summer seasons when the pools were not discharged (drained) regularly by rainwater coming from the terrace. It can thus be concluded that an unknown etiological agent is commonly transferred by the air, but at the most field Aldrovanda sites, its abundance (and thus infectivity) is controlled by unknown ecological factors (e.g., filtration by zooplankton, drifting away by discharging water). Whereas in stagnant cultures in aquaria or containers, the agent is not controlled and can propagate to cause the disease. Moreover, physiological state of the plants (rapid growth, flowering vs. poor conditions) is also responsible for the infectivity or sensibility of the plants. Finally, the disease has been known by many Aldrovanda growers over the world: in Europe, USA, Japan, as well as in Australia.

Since 1994, we have tried to ascertain the reasons of this disease. As the disease infects rapidly growing shoot apices but no visible parasites have been found in ill apices, a disorder of mineral nutrition (deficiency of microelements) was looked for firstly. Indeed, in some cases, after boric acid $\left(\mathrm{H}_{3} \mathrm{BO}_{3}\right)$ was added to culture medium at $0.6 \mathrm{mg}$ $1^{-1}$, plant growth resumed and ill shoot apices returned to good health after a few weeks (Adamec 1997). Yet the boron addition did not cure 
ill plants in many other cases. Furthermore, analyses of boron in Aldrovanda shoot tissue confirmed no difference in B content between ill and healthy plants and the same applied for other essential microelements (Fe, Mn, $\mathrm{Zn}, \mathrm{Cu}, \mathrm{Mo}, \mathrm{Co}$; Adamec 2003, 2007). The boron addition to ill plants could act within cell walls of shoot apices and change their mechanical properties (enforcement; e.g., Brown et al. 2002) and, thus, rendering cell walls less susceptible to the agent of the disease.

Later, parasitic etiological agents were looked for. A targeted virus inspection excluded the presence of several RNA viruses as the agent of this disease (A. Hehn, unpubl. res.). In 2004, the renowned Czech fungal phytopathologist Prof. Aleš Lebeda found an unknown species of a mold of the genus Fusarium and of Deuteromycetes as potential agents of the disease in ill shoot apices (A. Lebeda, unpubl. res.). This finding was supported by the fact that some

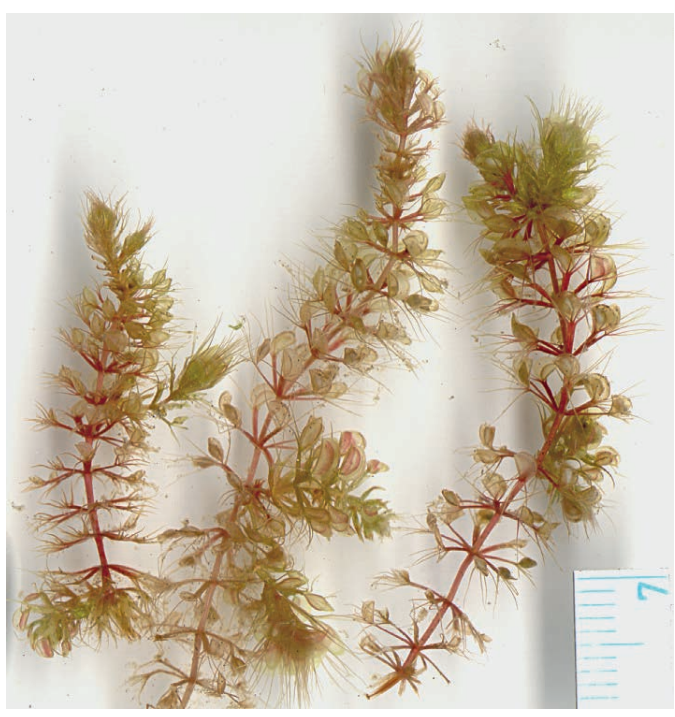

Figure 4: Regeneration of ill Australian Aldrovanda plants after three weeks after Topsin $\mathrm{M}$ application. New healthy branches were initiated from leaf axils and have long bristles. Ticks represent $1 \mathrm{~mm}$. Photo by Lubomír Adamec. fungicides could reliably cure the disease (Adamec 2007). Out of all tested fungicides, only wide-spectrum Topsin $\AA$ M (methyl-thiophanate) at a dose of 50-80 $\mathrm{mg} \mathrm{l}^{-1}$ reliably cured ill plants (both temperate and (sub)tropical strains), which could form healthy axillary branches and regenerate during 2-3 weeks (Fig. 4). A preparation Amistar ${ }^{\circledR}$ (azoxystrobin) at 70-100 $\mathrm{mg} \mathrm{l}^{-1}$ was also effective but simultaneously damaged the plants themselves and killed all aquatic snails. Amistar ${ }^{\circledR}-O p t i$ (mancozeb) at $100 \mathrm{mg}^{-1}$ strongly damaged ill plants. However, the ill plants cannot be treated with the suspension of Topsin $\mathrm{M}$ beyond the aquarium or container for only 2-3 days, but the fungicide must be added to the whole bulk of the culture water.

The aim of the paper is to preliminarily describe the fungal etiological agent causing the $\mathrm{Al}$ drovanda disease and to discuss important questions relating to further research in this field.

\section{Methods}

Ill Aldrovanda plants were collected from outdoor cultures of the volume of 3-300 1 for which Carex litter was used as the substrate (Adamec 1997, 2007). Ill Utricularia aurea (from tropical Asia) was grown similarly in a 3-1 aquarium in an open greenhouse. Soft tap water was used for all cultivations.

According to visible symptoms, three inspection methods were used. The first one was an immunochemical analytical method ELISA-Phytophthora ImmunoStrip. The method is designed for onsite testing of plant tissues suspected from an infection with various Phytophthora species. The test is recommended for use as a preliminary screening tool. It is known to cross-react also with some species of Pythium. Using this method, it is possible to directly confirm or eliminate the presence of fungal pathogen of the genera Phytophthora or Pythium in plant tissues (OEPP/EPPO 2006). 
After the results from the first method had been found positive, a cultivation on a nutrient medium PARP $(\mathrm{H})$ was used as another method. The genera Phytophthora and Pythium (Oomycetes, a nonphotosynthetic group of Stramenopiles or heterokonts, that also contain photosynthetic organisms like, e.g. brown, golden, and yellow-green algae) are metabolically and phylogenetically different from the "true fungi" (belonging to the opisthokonts, which are generally non-photosynthetic and also contain the animals) and this difference has been exploited in the development of a selective antibiotic medium. Relatively low growth rates of isolates of most species of Phytophthora and Pythium on culture media, as compared with those of many saprophytic fungi and bacteria, often present a problem. The used medium was selective for both tested genera and contained antibiotics pimaricin, ampicillin, and rifampicin, which inhibit overgrowing by undesirable faster growing pathogens. For cultivation on the nutrient medium, parts of plants with visible symptoms of the infection were also used. The genus Phytophthora belongs to biotrophic organisms and cannot be cultivated from dead host tissues. It is thus necessary to use only parts from the margin of the infected tissue so that they contain both ill- and healthy-looking tissue. Surface sterilization of samples is an important step of any fungal isolation. Therefore, $0.5-1 \mathrm{~cm}$ long shoot segments were disinfected in $1 \% \mathrm{NaOH}$ solution for 30 seconds, washed in sterile water and placed in a Petri dish with the nutrient medium. The Petri dishes were placed in the darkness and cultivated at $22-24^{\circ} \mathrm{C}$ (modified methodology according to Erwin \& Ribeiro 1996). Generally, this approach is recommended for isolation of Oomycetes. After 3-4 days, mycelium and other propagating particles like oospores (sexual spores) or chlamydospores and sporangia with moving zoospores (asexual spores) occurring inside were observed. In the case, when only sterile mycelium (without propagating particles) was observed, it was transferred to a vegetable medium, which supports formation of propagating particles.

However, in some cases, no formation of spores even after transferring to the vegetable medium was observed and no identification of the sterile mycelium was possible. In these cases, the third method was used - PCR (polymerase chain reaction) with DNA sequencing of the product. This method was also used in the last cultivation for mycelium with sexual and asexual spores for determination within the genus Pythium (OEPP/EPPO 2006).

\section{Results and Discussion}

The results of all methods used are summarized in Table 1. In the first year of testing, ELISA only from damaged Aldrovanda (Switzerland) tissues was positive. Damaged plant material from Switzerland, Poland, and Australia was also tested by isolation on the nutrient agar. Only sterile mycelium was isolated from the damaged Aldrovanda tissues even after a re-inoculation on the vegetable agar as the mycelium did not create any spores. The positive result of the sequencing thus could not be confirmed by microscopy, but corresponded to a positive result from the ELISA. In the second year of testing, the ELISA was positive and isolations on nutrient agar were positive, too. Negative results from ELISAs were probably influenced by using fungicides. The sterile mycelium was isolated again, but after a re-inoculation on the vegetable agar, it started forming oospores (Fig. 5). The mycelium from all isolations was white, airy and covered the whole Petri dish within one week. Although the results from different ill materials and the two test years are partly ambiguous, it can be suggested that the disease could be due to a fungal pathogen from the Pythiaceae family: either from the genus Phytopythium or Pythium, which are very similar. All isolates were identified to species using DNA sequencing techniques.

Results of PCR with sequencing were different between the first and second testing year (Table

1). Three different ITS sequences were obtained from the samples and were compared with those 
Table 1. Summary of populations inspected for the Aldrovanda (AV) disease, used methods and results. The ELISA test detects the genus Phytophthora and selected species of Pythium. *, III plants treated by Amistar about one month before sampling but many smaller plants remained ill - these were sampled.

\begin{tabular}{|l|c|c|l|l|l|}
\hline $\begin{array}{c}\text { Species and ill } \\
\text { population }\end{array}$ & $\begin{array}{c}\text { Date of } \\
\text { sampling }\end{array}$ & $\begin{array}{c}\text { Disease } \\
\text { symptoms }\end{array}$ & $\begin{array}{l}\text { Plant tissue/ } \\
\text { pure culture }\end{array}$ & Used methods & \multicolumn{1}{|c|}{$\begin{array}{c}\text { Result of the } \\
\text { investigation }\end{array}$} \\
\hline AV: Switzerland & June 2017 & stem & Plant tissue & ELISA & positive \\
\hline AV: Switzerland & June 2017 & stem & Pure culture & PCR+sequencing & $\begin{array}{l}\text { Phytopythium } \\
\text { oedochilum }\end{array}$ \\
\hline AV: E Poland & Sep. 2017 & apex & Pure culture & PCR+sequencing & $\begin{array}{l}\text { Phytopythium litorale, } \\
\text { Pythium sterile }\end{array}$ \\
\hline AV: SE Australia & Sep. 2017 & apex & Pure culture & PCR+sequencing & $\begin{array}{l}\text { Phytopythium } \\
\text { oedochilum }\end{array}$ \\
\hline AV: E Poland & June 2018 & apex & Plant tissue & ELISA & positive \\
\hline AV: E Poland & June 2018 & apex & Pure culture & PCR+sequencing & Pythium sp. \\
\hline AV: Romania* & June 2018 & stem & Plant tissue & ELISA & negative \\
\hline AV: E Poland & June 2018 & apex & Pure culture & PCR+sequencing & $\begin{array}{l}\text { Pythium coloratum, } \\
\text { P. dissotocum }\end{array}$ \\
\hline AV: E Poland & July 2018 & apex & Pure culture & PCR+sequencing & $\begin{array}{l}\text { Pythium coloratum, } \\
\text { P. dissotocum, } \\
\text { P. diclinum }\end{array}$ \\
\hline Utr: aurea: Asia & June 2018 & apex & Plant tissue & ELISA & positive \\
\hline
\end{tabular}

available in the GenBank database. In 2017, results showed mainly the genus Phytopythium, but in 2018, they showed only the genus Pythium. In 2017, the found etiological agent (Phytopythium oedochilum) was the same both for the stem and apical symptom of the disease. Both symptoms can thus be considered different forms of the same disease caused by the same agent. Moreover, it is highly probable that the species of Pythium/Phytopythium can also infect ecologically similar (but taxonomically dissimilar) aquatic Utricularia species and cause a similar disease (Table 1). On the
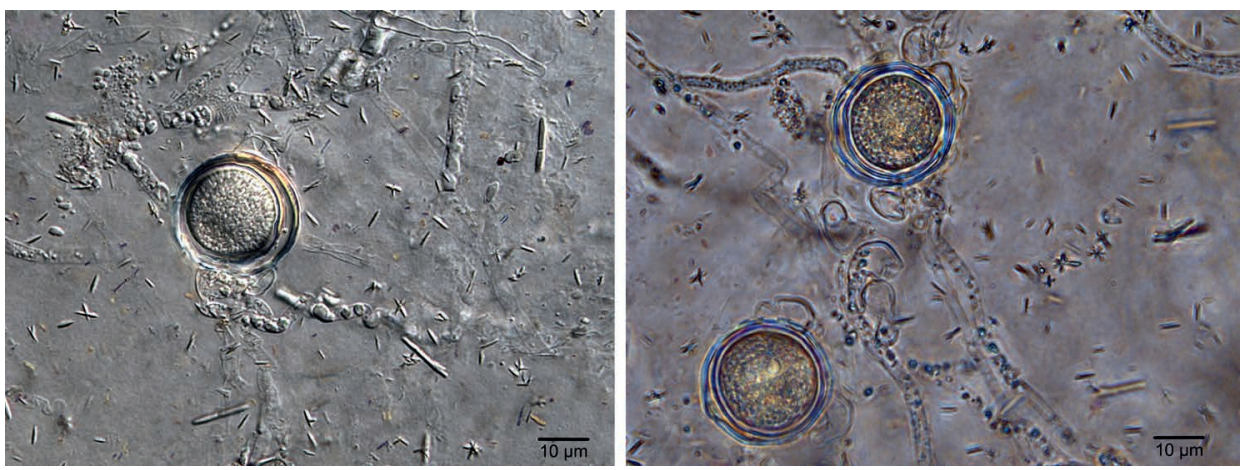

Figure 5: Left: Oospores of Pythium dissotocum, isolation from the shoot apex of Aldrovanda vesiculosa, E. Poland, mean size $23.8 \mu \mathrm{m}$. Right: Oospores of Phytopythium spp., isolation from the shoot apex of Aldrovanda vesiculosa, E. Poland, mean size 24.2 $\mu \mathrm{m}$. Photos by I. Svobodová. 
other hand, Polish Aldrovanda plants without visual symptoms, thus considered healthy, were tested as controls. No fungal pathogen was detected on the medium.

Pythium and Phytophthora are two important genera of Oomycetes responsible for causing diseases in a variety of terrestrial plants. Many Pythium species, along with the closely related genus Phytophthora, are plant pathogens of a great economic importance in agriculture (Jarvis 1992). Pythium spp. tend to be very generalistic and unspecific in their large range of hosts, while Phytophthora spp. are generally more host-specific. For this reason, Pythium spp. are more devastating in the root rot they cause in crops, because crop rotation alone often may not eradicate the pathogen: Pythium spp. also behave as typical saprotrophs and survive on decaying plant matter for a long time (Owen-Going 2002).

In field crops, damage by Pythium spp. is often limited to the area affected, as the motile zoospores require ample surface water to travel for long distances (Owen-Going 2002). Additionally, the capillaries formed by soil particles act as a natural filter and effectively trap many zoospores. However, in hydroponic systems inside greenhouses, where extensive monocultures of plants are maintained in a continuously recirculating mineral nutrient solution (containing all macro- and micronutrients), Pythium spp. cause an extensive and devastating root rot, which is often difficult to prevent or control (Jarvis 1992). The root rot affects entire greenhouse compartments (tens of thousands of plants, in many instances) within two to four days due to the inherent nature of hydroponic systems where roots are freely exposed to the water medium, in which the zoospores can move freely (Bagnall 2007).

Species of Pythium can live saprophytically or parasitically. Their parasitic role often depends on external factors. Under the conditions favorable for the fungus but less for the host, Pythium species can become very pathogenic and cause rot of fruit, roots or stems, pre- or post-emergence dampingoff of seeds and seedlings. Young or water-rich tissues are preferentially attacked (Plaats-Niterink 1981). Aldrovanda is well-known to have fine and fragile tissues especially in rapidly growing shoot apices (Adamec 2018a) where the disease starts most frequently.

Phytopythium is a new genus in the family Pythiaceae, order Perenosporales. The genus Phytopythium has been described, but its complete circumscription has not yet been presented. Phytopythium is morphologically intermediate between the genera Phytophthora and Pythium. It is unique in having papillate, internally proliferating sporangia, and cylindrical or lobate antheridia (Cock et al. 2015). The species Phytopythium oedochilum (Drechsler) (Cock et al. 2015) was recombined in 2014 and before, it was described as Pythium oedochilum (Drechsler 1930). Recently, the latter name is used as a synonym. Similarly, the species Phytopythium litorale (Nechw.) (Cock et al. 2015) was earlier determined as Pythium litorale (Nechwatal \& Mendgen 2006). The genera Pythium and Phytopythium also attack aquatic plants or can live in aquatic environments. For example, Phytopythium helicoides has been confirmed as a causative agent of the rhizome rot of Asian lotus (Nelumbo nucifera) in China (Yin et al. 2016). Several species of both genera were also isolated from bottom sediments, algae, and decaying plant debris in freshwater streams of Korea (Nam \& Choi 2019).

The questions remain where and how the infection takes place. Is it probably present permanently in Aldrovanda plants or in overwintering turions or only in the ambient culture water or litter? In such water, no fungal structures reminding Pythium/Phytopythium hyphae or spores have ever been detected microscopically (Adamec, unpubl. res.). In the spring, once the conditions suitable for propagation occur, the pathogen begins to spread again in the culture water and the symptoms appear. Nevertheless, the etiology of the disease and casual infection of Aldrovanda in covered mini-aquaria may indicate that the pathogen (probably as sporangium) can be spread repeatedly 
by wind. On the other hand, the ELISA confirmed the presence of Phytophthora or Pythium also in two used samples of Carex litter from two aquaria with both ill and healthy Aldrovanda plants. This finding may suggest that the etiological agent is present permanently in the submerged litter as substrate and it is only the physiological condition (susceptibility) of the plants that determines whether or not they are infected.

Yet the basic question to be answered is why the disease is not present (or very rarely) in fieldgrowing Aldrovanda plants when the growth conditions are comparable with those in the opened cultures in larger containers? It is possible to assume that certain biotic factors (e.g., filtration by zooplankton or other filtrators) permanently reduce the abundance of the pathogen (oospores, Fig. $5)$ to a minimum in the ambient water at field sites so that the plants are only rarely infected. Therefore, finding such biotic interactions responsible for eliminating the pathogen in aquatic habitats could be an effective key for a biological control in Aldrovanda cultures. Otherwise, the propagation of the Pythium/Phytopythium pathogen in the water is very rapid and a large number of pathogen spores can infect the plants within a short time. The effect of the biological control of the pathogen oospores by filtrators could theoretically be ensured by a submersible UV sterilizer with filter pump used for aquaria (cf. Zhang \& Tu 2000). However, a permanent operation of a UV sterilizer (SunSun JUP-02 Sterilizer, 5 W UV-C) in a 300-1 container with ill Aldrovanda plants in a greenhouse did not cure the plants at all (L. Adamec, unpubl. res.). Yet such a UV sterilizer could effectively reduce the abundance of pathogen spores and rather prevent the infection of healthy plants.

\section{Conclusions}

An immunochemical analytical method, cultivation on nutrient media and PCR with DNA sequencing were used to determine the pathogen causing the Aldrovanda disease. Based on these methods, the fungal pathogen of the genera Phytopythium and Pythium of the class Oomycetes was repeatedly found to probably cause the disease. To confirm this conclusion, it would be necessary to perform pathogenicity tests to verify that isolated fungal organisms cause observed symptoms on plants during their growth. It follows from limited data that the pathogen occurs permanently in the sedge litter in aquaria or containers, but the factors responsible for its pathogenicity remain unknown.

Acknowledgements: This study was funded partly by the Research Programme of the Czech Academy of Sciences (No. RVO 67985939). Sincere thanks are due to Dr. Alain Hehn for virological inspection of ill Aldrovanda plants. Special thanks are due to Dr. Jan Schlauer for critically reading the manuscript and valuable comments.

\section{References}

Adamec, L. 1997. How to grow Aldrovanda vesiculosa outdoors. Carniv. Pl. Newslett. 26: 85-88.

Adamec, L. 2003. Ecophysiological comparison of green Polish and red Australian plants of $\mathrm{Al}$ drovanda vesiculosa. Carniflora Aust. 1: 4-17.

Adamec, L. 2007. Micronutrient content does not reflect the status of health in the aquatic carnivorous plant Aldrovanda vesiculosa. Biologia 62: 711-714.

Adamec, L. 2018a. Biological flora of Central Europe: Aldrovanda vesiculosa L. Perspect. Plant Ecol. Evol. Syst. 35: 8-21.

Adamec, L. 2018b. Ecophysiology of aquatic carnivorous plants. In: Carnivorous Plants: Physiology, Ecology, and Evolution. Ellison, A.M., and Adamec, L. (eds.). Oxford University Press, Oxford, U.K., pp. 256-269. 
Adamec, L. 2018c. Germination rate and longevity of seeds of Aldrovanda vesiculosa and Utricularia vulgaris. Carniv. P1. Newslett. 47: 64-69.

Bagnall, R. 2007. Control of Pythium wilt and root rot of hydroponically grown lettuce by means of chemical treatment of the nutrient solution. MSc thesis. University of Pretoria, South Africa.

Breckpot, C. 1997. Aldrovanda vesiculosa: Description, distribution, ecology and cultivation. Carniv. P1. Newslett. 26: 73-82.

Brown, P.H., Bellaloui, N., Wimmer, M.A., Bassil, E.S., Ruiz, J., Hu, H., Pfeffer, H., Dannel, F., and Römheld, V. 2002. Boron in plant biology. Plant Biol. 4: 205-223.

Cock, A.W.A.M. de, Lodhi, A.M., Rintoul, T.L., Bala, K., Robideau, G.P., Gloria Abad, Z., Coffey, M.D., Shahzad, S., and Lévesque, C.A. 2015. Phytopythium: molecular phylogeny and systematics. Persoonia 34: 25-39.

Cross, A.T. 2012. Aldrovanda. The Waterwheel Plant. Redfern Natural History Production, Poole, Dorset, U.K.

Cross, A.T., Adamec, L., Turner, S.R., Dixon, K.W., and Merritt, D.J. 2016. Seed reproductive biology of the rare aquatic carnivorous plant Aldrovanda vesiculosa (Droseraceae). Bot. J. Linn. Soc. 180: 515-529.

Drechsler, C.F. 1930. Some new species of Pythium. J. Wash. Acad. Sci. 20: 398-418.

Elansary, H.O.M., Adamec, L., and Štorchová, H. 2010. Uniformity of organellar DNA in Aldrovanda vesiculosa, an endangered aquatic carnivorous species, distributed across four continents. Aquat. Bot. 92: 214-220.

Erwin, D.C., and Ribeiro, O.K. 1996. Phytophthora diseases worldwide. APS Press, Saint Paul, Minnesota, USA.

Jarvis, W.R. 1992. Managing diseases in greenhouse crops. APS Press, Saint Paul, Minnesota, USA.

Nam, B., and Choi, Y.J. 2019. Phytopythium and Pythium species (Oomycota) isolated from freshwater environments of Korea. Mycobiology 47: 261-272.

Nechwatal, J., and Mendgen, K. 2006. Pythium litorale sp. nov., a new species from the littoral of Lake Constance, Germany. FEMS Microbiol. Lett. 255: 96-101.

OEPP/EPPO. 2006. Phytophthora ramorum. Bulletin OEPP/EPPO 36: 145-155.

Owen-Going, N.T. 2002. Etiology and epidemiology of Pythium root rot in bell pepper (Capsicum annuиm L.) in commercial-scale and small-scale hydroponic systems. MSc thesis. University of Guelph, Canada.

Plaats-Niterink, J. van der. 1981. Monograph of the genus Pythium. Studies in Mycology. No. 21: $1-244$.

Yin, X., Li, X.Z., Yin, J.J., and Wu, X. 2016. First report of Phytopythium helicoides causing rhizome rot of Asian Lotus in China. Plant Disease 100: 532-533.

Zhang, W., and Tu, J.C. 2000. Effect of ultraviolet disinfection of hydroponic solutions on Pythium root rot and non-target bacteria. Eur. J. Plant Pathol. 106: 415-421. 


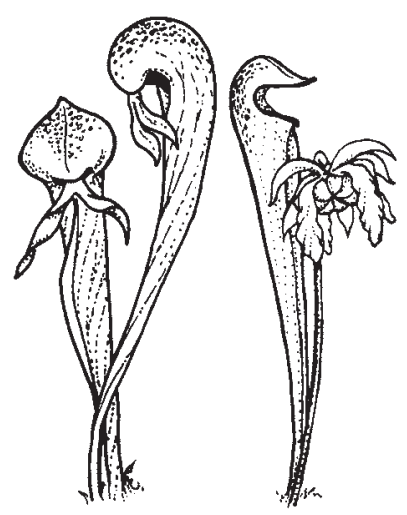

\section{CARNIVOROUS \\ PLANT \\ NEWSLETTER}

Journal of the International

Carnivorous Plant Society

www.carnivorousplants.org

\section{Volume 49, Number 2 June 2020}

Front Cover: The cultivar Pinguicula 'Razzberry Blonde'. Photo by Mark Rubnitz. Article on page 90.

Back Cover: Ripening dormant turions of red Aldrovanda vesiculosa formed in an indoor aquarium over winter. The plants originate from mountains near Armidale, N.S.W., Australia. Photo by Lubomír Adamec. Article on page 56.

Carnivorous Plant Newsletter is dedicated to spreading knowledge and news related to carnivorous plants. Reader contributions are essential for this mission to be successful. Do not hesitate to contact the editors with information about your plants, conservation projects, field trips, or noteworthy events. Advertisers should contact the editors. Views expressed in this publication are those of the authors, not the editorial staff.

All correspondence regarding dues, address changes and missing issues should be sent to the Membership Coordinator at the ICPS. Do not send such correspondence to the editors. Checks for subscriptions should be made to the International Carnivorous Plant Society in US funds. Dues, including a subscription, are \$30 per year.
International Carnivorous Plant Society, Inc.
2121 N. California Blvd., Suite 290
Walnut Creek, CA 94596-7351, USA
icps@carnivorousplants.org

$\begin{array}{ll}\text { President } & \text { Richard Nunn, richardnunn@carnivorousplants.org } \\ \text { Vice President } & \text { John Brittnacher, john@carnivorousplants.org } \\ \text { Secretary } & \text { Cindy Slezak, cindy@carnivorousplants.org } \\ \text { Treasurer } & \text { Daniela Ribbecke, daniela@carnivorousplants.org } \\ \text { Board Member } & \text { Brent Jones, Conservation Director, brent@carnivorousplants.org } \\ \text { Board Member } & \text { Kenny Coogan, Education Director, kenny@carnivorousplants.org } \\ \text { Board Member } & \text { Jan Schlauer, Cultivar Registrar, jan@carnivorousplants.org } \\ \text { Board Member } & \text { Bob Ziemer, bob@carnivorousplants.org } \\ \text { Membership Coordinator } & \text { Cindy Slezak, cindy@carnivorousplants.org } \\ \text { Webmaster } & \text { John Brittnacher, john@carnivorousplants.org } \\ \text { Media Coordinator } & \text { Chad Williams, chad@carnivorousplants.org } \\ \text { Seed Bank Manager } & \text { Joe Griffin, joe@carnivorousplants.org } \\ \text { CPN Editors } & \text { editor@carnivorousplants.org } \\ \text { Managing Editor } & \text { Bob Ziemer } \\ \text { Editor } & \text { Barry Rice } \\ \text { Editor } & \text { Karl Herold } \\ \text { Editor } & \text { John Brittnacher } \\ \text { Science Editor } & \text { Andreas Fleischmann } \\ \text { Science Editor } & \text { Fernando Rivadavia } \\ \text { Science Editor } & \text { Jan Schlauer }\end{array}$

Date of effective publication of the March 2020 issue of Carnivorous Plant Newsletter: February 7, 2020.

The ICPS is the International Cultivar Registration Authority (ICRA) for the names of cultivated carnivorous plants according to the International Code of Nomenclature for Cultivated Plants. Send relevant correspondence to the ICPS, Inc.

Carnivorous Plant Newsletter is published quarterly in March, June, September, and December by the ICPS, Inc., 2121 N. California Blvd., Suite 290, Walnut Creek, CA 94596, USA. Periodicals postage paid at Walnut Creek, CA and additional mailing offices. Postmaster: Send address changes to ICPS, Inc., 2121 N. California Blvd., Suite 290, Walnut Creek, CA 94596, USA. Printed by Allen Press, Inc., 810 E. 10th Street, Lawrence, KS 66044. Logo and masthead art: Paul Milauskas. (C) 2020 International Carnivorous Plant Society. All rights reserved. ISSN \#0190-9215 